\title{
Miranda
}

Revue pluridisciplinaire du monde anglophone /

Multidisciplinary peer-reviewed journal on the English-

speaking world

$6 \mid 2012$

Marking the Land in North America

\section{The Everglades Ecosystem: Under Protection or Under Threat?}

Janine Lemaire and Bénédicte Sisto

\section{OpenEdition}

\section{Journals}

\section{Electronic version}

URL: http://journals.openedition.org/miranda/2881

DOI: $10.4000 /$ miranda.2881

ISSN: 2108-6559

Publisher

Université Toulouse - Jean Jaurès

\section{Electronic reference}

Janine Lemaire and Bénédicte Sisto, "The Everglades Ecosystem: Under Protection or Under Threat?", Miranda [Online], 6 | 2012, Online since 28 June 2012, connection on 16 February 2021. URL: http:// journals.openedition.org/miranda/2881 ; DOI: https://doi.org/10.4000/miranda.2881

This text was automatically generated on 16 February 2021.

\section{cc) (i) () $\Theta$}

Miranda is licensed under a Creative Commons Attribution-NonCommercial-NoDerivatives 4.0 International License. 


\title{
The Everglades Ecosystem: Under Protection or Under Threat?
}

\author{
Janine Lemaire and Bénédicte Sisto
}

1 Florida has 1,800 miles of coastline and is known around the world for its beaches covered with the finest white sand. With the rise of the Sunbelt, the Sunshine State saw its population grow dramatically over the twentieth century, shifting from one of the least populated states in the country, with only half a million inhabitants in 1900, when it was placed 23rd in state rankings, to one of the fastest growing states. In the year 2010, with nearly nineteen million inhabitants, it was the fourth most populated state in the United States after California, Texas and New York, and more than $94 \%$ of Florida's population lived in metropolitan areas, mostly in counties located in Central and Southern Florida. ${ }^{1}$ The massive influx of new residents driven by the desire to escape the harshness of Northern winters in an exotic Southern setting, combined with the boom in the state's tourism industry after World War II, led to the fast development of leisure, vacation and retirement cities, especially along the coasts (Stronge, 157-161). In Central Florida, not only cities but also huge vegetable and citrus farms as well as vast sugar plantations kept sprawling south of Lake Okeechobee, Florida's greatest lake and the second largest freshwater lake in the United States after Lake Superior.

2 The Everglades, a vast network of tropical swamps and rivers located in the Southern part of Florida, run from Lake Okeechobee down through the southern tip of the state, and were once a place that was extremely rich in subtropical vegetation and wildlife. But half of the historic Everglades have been drained and no longer exist, while the Everglades National Park struggles to survive with water levels that are only half of what they were fifty years ago. How did such a dramatic shift happen, and what is the current status of the Everglades ecosystem? Today, is the site under protection, or is it still under threat? This paper describes the man-made changes that have severely altered the Everglades since the end of the nineteenth century, and examines the present situation and potential for survival of this ecosystem. In our study, we will explain how these unique wetlands, the largest subtropical wilderness in the United States, were gradually manipulated by developers and farmers eager to see drainage 
canals drying out large tracts of marshland; how the large number of canals constructed since the 1880s severely damaged the Everglades by shutting off the natural flow of freshwater while contaminating the water with chemicals sent downstream from farms; how, after decades of mismanagement including repeated unsuccessful attempts to protect and later preserve its natural environment ${ }^{2}$, the Everglades is now the site of a billion-dollar restoration plan aimed at reversing decades of ecological decline. Finally, this paper suggests that America's largest civilengineering project to save the Everglades, although it may slow the rate of decline, is very unlikely to return the ecosystem to its previous stable state.

\section{The historic Everglades}

Florida is one of North America's wettest regions with more than 1,700 streams and rivers, 7,800 freshwater lakes, 700 springs and 11 million acres of wetlands. ${ }^{3}$ The Everglades are a unique ecosystem because their water only comes from rainfall, which means that they are independent of a river. Another feature is the outpouring of freshwater creating a "sheet flow" from Central to Southern Florida. The result is that the area consists in a flat wetland regularly covered by shallow water. The patterns of the Everglades are caused by the yearly cycle of rain in spring and summer and drought in winter. The rains that fall on Central Florida join with the overflow from Lake Okeechobee and are carried southward until they evaporate and fall again as rain, enter the ground to go back to the aquifer and run into the sea in the estuaries. To sum up, the Everglades is a region fed by a flow of water.

4 The Everglades is characterized by an unusually rich biodiversity. The main types of landscapes and vegetation found in the Everglades are wetland marshes and prairie, often blending into each other or existing next to each other. The prairies support the greatest concentration of sawgrass in the world, a plant which, because of its sharp leaves, used to make journeys of exploration very difficult, if not impossible, even where the waters were not too deep. ${ }^{4}$ In this watery world, many small tree islands emerge above the sawgrass. In the driest parts of the Everglades, pinelands consisting of slashpine with an undergrowth of palmettos and tropical plants constitute a very diverse habitat. Cypresses which can grow with their roots in the water are very typical of Big Cypress Swamp which looks like a tropical jungle. Near the sea, where fresh water mixes with salt water, the mangrove, the largest in the western hemisphere, is the dominant vegetation and protects uplands from storm winds, waves, and floods. ${ }^{5}$ off the coast of southwest Florida, the land breaks into a multitude of small islands in the "Ten Thousand Islands." 


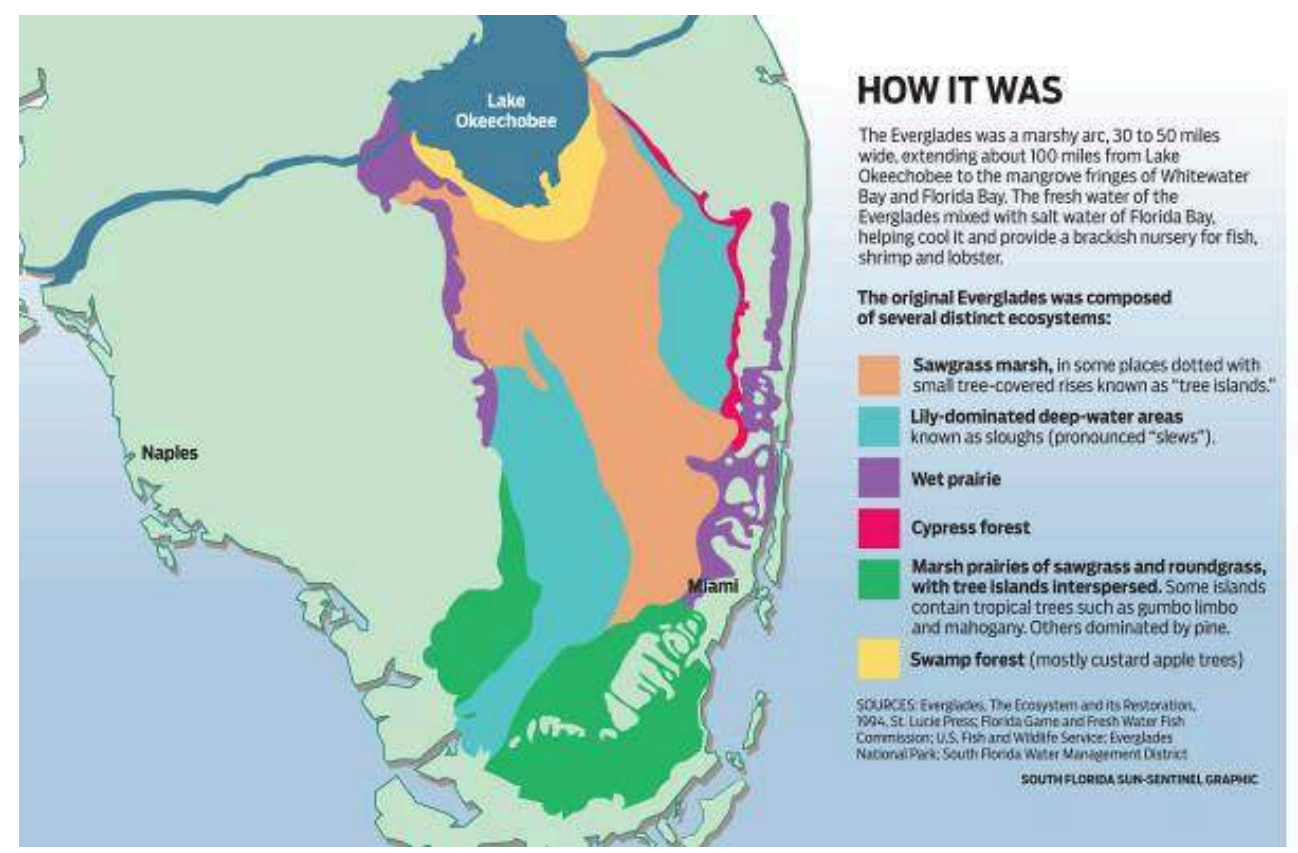

5 Originally, the Everglades covered 4 million acres and comprised the entire southern third of Florida, constituting an uninterrupted stretch of marshes extending from Lake Okeechobee to Florida Bay. During the historical cycle, it consisted in a flow of water beginning near the present location of Orlando and controlled by a balanced mechanism. Surface water flowed from the Kissimmee River and several smaller streams ended in Lake Okeechobee. Then, in the summer, the water level of the lake rose and the water moved imperceptibly towards the Southern tip of Florida into Florida Bay. The region situated south of Orlando was almost completely covered by a low seasonally flooded wetland. The Northern Everglades were characterized by a saw grass plain which gave way to a more varied landscape in the central and southern parts of the region. Through the interior, deep, open-water sloughs edged with ridges of saw grass and tree islands were scattered in the landscape. Along the edges of the Everglades, wet prairies consisted in a rich variety of marsh plants and, more to the south, the region contained a great range of tropical plants. The immensity of the ecosystem also made possible the existence of a diverse habitat that supported an abundant fauna. As Ted Levin sums up, "during wet periods, the marl prairie became a biological Mecca" (Levin, 221). With such an exceptional variety of water habitats, the Everglades provided a sanctuary for numerous species of plants, mammals, fish, reptiles and birds like snail kites and Cape Sable sparrows, and the sawgrass prairie was the most significant breeding ground for wading birds in North America. Wildlife also included extremely rare species like the Florida panther, alligator, crocodile, indigo snake, mink, grey fox and manatee. ${ }^{6}$

During the first half of the nineteen ${ }^{\text {th }}$ century, at a time when American pioneers were conquering Western territories, many explorers described Florida's wilderness as inaccessible and extremely inhospitable: seasonally flooded, it was said to be an ugly and worthless mosquito-infested alligator swamp where it was "unpredictable to settle" (Grunwald, 4). In 1848, three years after Florida entered the Union, Congress asked for a survey of the Everglades. The report stated that "the elevation of the Everglades proved the capability of being drained" (Grunwald, 60). It suggested widening and deepening the existing rivers as well as Lake Okeechobee, and building 
canals East and West of the lake in order to let the water run into the ocean. It concluded that draining swamps and creating dry land that could then be farmed and built upon could be done easily for minimum costs, transforming Southern Florida into a pioneer's paradise.

7 It took four more decades before the possible drainage mentioned in this report turned into a reality. In the early 1880 s, the region of present-day Orlando was considered as the extreme South and few people other than Seminole Indians and a few outlaws ventured into South Florida's interior. The first man to start developing part of this vast territory for economic purposes was Hamilton Disston, the son of Henry Disston, one of the pioneers in the steel industry of Pennsylvania. Hamilton was associated with his father and brothers in the manufacturing of the world-famous Disston saws. A very rich young man, he was on vacation in Jacksonville when he first saw the Everglades in the region of present-day Orlando, a region which was virtually uninhabited. In this part of the country so incredibly difficult to access, Disston soon became fascinated with the possibility of draining swamp land for agricultural and residential purposes, being convinced that these wetlands could be drained easily by digging canals. In January 1881, he met with Florida governor William Bloxham, offering "to reclaim by drainage an unspecified number of acres in the general vicinity of Lake Okeechobee." 7 Bloxham agreed on this project for two reasons: first, because the Swamp Land Act of 1850 had transferred wetlands from the federal government to the states, which meant that the Florida governor was able to give most of the submerged lands (twenty million acres) to developers in exchange for drainage projects, and developers could then sell the wetlands if they were deemed drainable for use in agriculture; secondly, because he explained he wanted "immigration and capital in Florida, come from whatever source it may" (Levin, 81). By the time Disston undertook his project, the West was being intensely explored and exploited, and westward expansion had given birth to the pioneer concept that nothing was impossible in America. The transcontinental railroad, the most ambitious human enterprise since the Great Wall of China, had changed the lives of settlers and transformed the heartland by accomplishing the dream of convenient, efficient transport to travel across the country. Clearly, Disston's ambitious project fitted perfectly within this new era of progress and innovation, as well as with the common belief that taming nature by removing the obstacles presented by the natural environment was necessary for the sake of civilization.

\section{The destruction of the natural ecosystem}

With the governor's blessing, Disston launched his huge-scale works to drain twelve million acres of wetlands, which corresponded to one third of the total area of Florida, and became the private owner of six million acres of drained land, that is, one sixth of the total area of Florida or the equivalent of the state of New Jersey, which made him the largest private landowner in America. In July 1881, Disston's Atlantic and Gulf Coast Canal and Lake Okeechobee Land Company issued 600,000 shares of stocks at \$10 a share and sold lots before the drainage had even started, opening real estate offices through America as well as Europe (Grunwald, 89). His advertising campaign mentioned a frostfree, illness-free, and mosquito-free paradise, and promised that these inexhaustibly rich lands would be perfect for farming. In his ads, he said that "the immigrant from Europe, or settler from other states, [could] find no more favorable location, and the 
capitalist no better investment" (Grunwald, 89). This ad campaign received immediate attention nationwide and gave birth to the very first land boom ever recorded in Florida history.

Aimed at making the Everglades habitable, the Disston drainage started in the mid-1880s north of Lake Okeechobee around present-day Orlando with the building of small canals along the Kissimmee River, the main river in Central Florida which flows into Lake Okeechobee. In a few years' time, the drainage opened new lands to farmersover 50,000 acres located in today's Walt Disney World Resort area-and lowered the level of Lake Okeechobee by $4 \frac{1}{2}$ feet. $^{8}$ The results were so impressive that they allowed Disston to sell his lots at very high prices and to start building his first sugarcane plantation on the site. ${ }^{9}$ However, during the wet season of 1887, the river flooded again and Disston was blamed by newly-settled farmers for building narrow, poor-quality canals. Hoping to resolve the problem, he started building more miles of wider canals, but the financial panic of 1893 left him totally bankrupt and, soon afterwards, he killed himself. If his heirs sold what remained of his land holdings after his death at a very low price, Hamilton Disston's drainage operation remains an event of statewide significance, paving the way for further, larger drainage projects which, during the following decades, exposed millions of acres of previously flooded land for development.

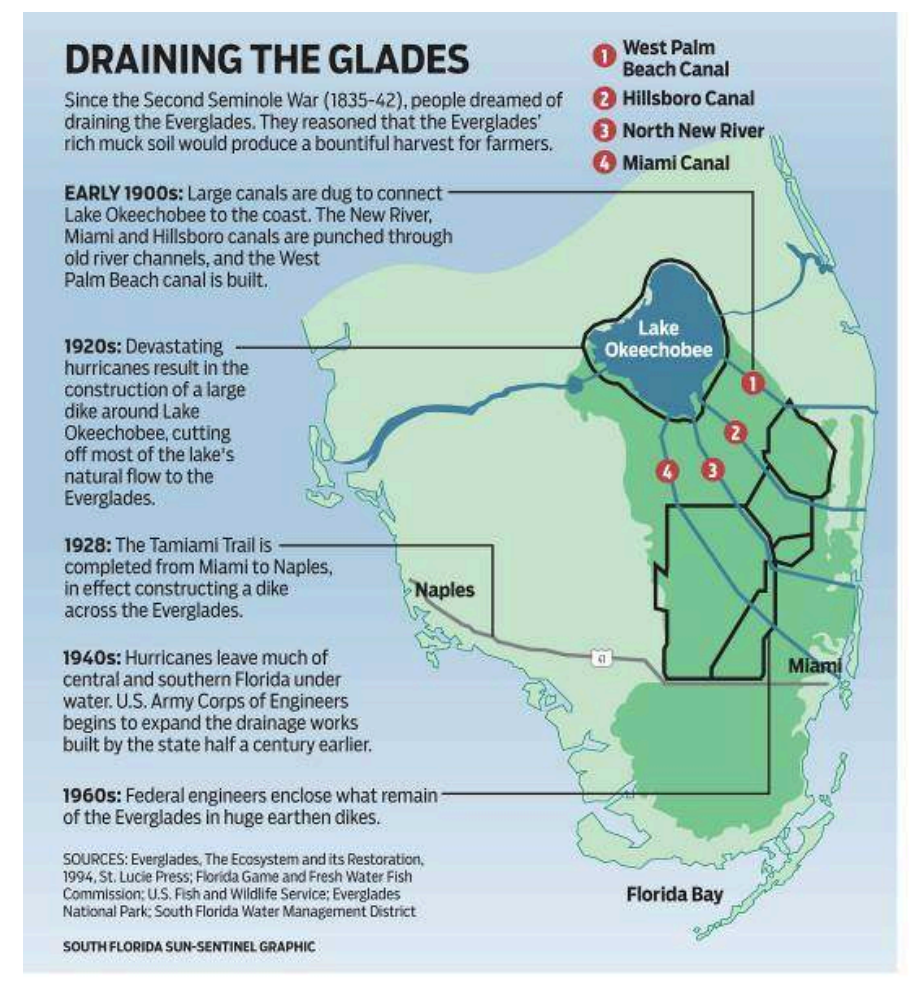

The second drainage was initiated by Florida governor Napoleon Bonaparte Broward in 1905. During his political campaign, Broward, who believed that the state should undertake this challenge, had said that he was ready to declare war on South Florida's water, a statement that was perfectly acceptable at the time. After being elected, Broward imposed a state land tax in order to finance his project, announcing that the drainage would be an easy job to do and last no longer than eighteen months. But it took about twenty years to build, more than anyone had anticipated. The first canal, the North New River Canal going from Fort Lauderdale to south Lake Okeechobee, was 
completed in 1912. Twenty thousand lots were sold in just a few months and farmers were soon able to grow vegetables around Fort Lauderdale. However, there were floods again soon afterwards and people started complaining that their promised land, supposed to be the most productive in the world, was still under water. The U.S. Department of Agriculture decided to send over an expert who had worked on the building of the Panama Canal to examine the situation. This expert considered that it was necessary to carry out a vast building project of five more canals. The Miami Canal and South New River Canal going from Lake Okeechobee to Miami were completed in 1913; the Hillsboro Canal from Lake Okeechobee to Boca Raton was completed in 1915; the West Palm Beach Canal, completed in 1920; and the St Lucie Canal, completed in 1926. However, nature continued to resist the drainage process when two great hurricanes devastated Central and Southern Florida, in 1926 and 1928, with floods killing thousands of people and leaving thousands of people homeless (McCally, 139). President Hoover, who saw the extensive damage when visiting Florida in early 1929, decided to send federal experts to the site to try and solve the problem for good. These experts decided on a radically different approach and adopted a new engineering project focused on flood control more than drainage in order to prevent hurricanes from blowing water out of the lake.

Determined to prevent disastrous floods in both agricultural and urban areas, the Army Corps of Engineers decided not only to dig new canals and deepen the old ones but also to build dikes, levees, and add pumping stations. In order to tame Lake Okeechobee, the biggest flood control project, which took ten years to build, was the Hoover Dike, a massive 20-foot-high dike that encircled the southern shore of the lake. Completed in March 1938, this new dike gave farmers the perception of security that they needed to double sugarcane production from 410,000 tons to 873,000 tons in the 10 years between 1931 and $1941 .{ }^{10}$ And yet, when two major hurricanes struck the state in 1947, they again caused extensive damage in Central and South Florida: canals overflowed again and water covered five million acres of Florida farmland for months, killing cattle and wildlife, and spreading typhoid.

It was not until the middle of the twentieth century that the nature of the Everglades ecosystem was understood by hydrologists, but a lot of damage had already been done. The massive drainage undertaken in the first half of the twentieth century had led to a reduction of the Everglades by half. This surface was now converted to agricultural and urban uses, while the remaining parts of the Everglades were vastly altered by the hydrological changes entailed by the flood control works. Drainage entailed drier conditions affecting the balance of the ecosystem. After drainage, fertile and productive prairies were still available but the natural watering system did not fit the farming requirements: the region became dry when plants needed water and there were occasionally very destructive floods. As David McCally points out in his book The Everglades, an Environmental History, after the Second World War, it became apparent that the drainage had been inadequate because the Everglades had become "a too-dry land. [...] To the dismay of drainage advocates, the removal of the Everglades' surface water threatened the viability of the very land that drainage created" (McCally, 140). Indeed, new problems had arisen as a direct consequence of over-drainage, like for example saltwater infiltration into Lake Okeechobee, damaging fires caused by drought, and the spread of invasive species-plants and animals-disturbing the natural balance of native species with devastating effects. 
13 As problems accumulated, the Everglades Drainage District was accused of sending excess water down the drainage canals, and the Federal Government ordered the Army Corps to find appropriate solutions in order to protect urban areas from flooding. Consequently, a fourth Everglades reclamation plan called The Central and Southern Florida Project for Flood Control and Other Purposes was initiated..$^{11}$ This 208-million-dollar project, almost entirely financed by the federal Government, lasted from 1950 to 1967. It consisted in enlarging the existing canals, extending the Hoover Dike so that the structure would surround Lake Okeechobee entirely, and building two thousand more miles of canals as well as several water storage areas. ${ }^{12}$ The project also included the creation of land-use areas subdividing the Everglades into the Everglades Agricultural Area (EAA) $)^{13}$, three Water Conservation Areas (WCA) functioning as reservoirs protecting the EAA and the lower east coast of Florida from floods and, most importantly, a national park. ${ }^{14}$

\section{The creation of the Everglades National Park and continuing deterioration}

The creation of the Everglades National Park took place in 1947 after a long fight to save the region from development. Harriet Beecher Stowe, the author of the best-seller Uncle Tom's Cabin (1852) and a resident of Florida since the end of the Civil War, was the very first person to publicly express concern for Florida's wildlife. In her 1877 book entitled Protect the Birds, she blamed rich Northern visitors travelling across north Florida during wintertime for shooting birds for pleasure. She also pointed at trappers killing tens of thousands of wood storks, green herons, snowy egrets, pelicans and flamingos in order to sell the birds for a fortune on the Northeast coast where the long colourful, decorative feathers were being used to adorn wealthy women's hats. Rebelling against this large feather trade, Stowe wrote: "It is perfect slave trade over again, and it is slowly and surely robbing our beautiful State of one of its chief attractions" (Levin, 190). Thirty years later, in the early years of the twentieth century, Florida governor William Sherman Jennings finally enacted Florida's first forest protection law which banned plume hunting, therefore saving wading birds from extinction.

During the following decades, many local conservationists denounced the drainage of large tracts of the Everglades and repeatedly but unsuccessfully asked for the region to become a protected area. Hope for change came with two very active participants in the crusade for the creation of an Everglades preserve, namely Marjory Stoneman Douglas and Ernest Coe. A young reporter on the Miami Herald, where her father was the chief editor, Marjory Stoneman Douglas first thought of transforming the Everglades into a wildlife preserve in the 1920s, insisting that the place should also be "a permanent home for the Seminoles" 15 who had taken refuge there to escape the U.S. army during the Third Seminole War of 1855-1858. Douglas spent the next twenty years collecting material for newspaper articles on the Everglades to be published all over the United States. In 1947, she wrote a very successful book entitled The Everglades: River of Grass. The text, starting with the sentence "There are no other Everglades in the world" (Douglas, 1974, 1), redefined the Everglades as a source of fresh water essential to both the people and wildlife of the region. 
Ernest Coe, an architect from Connecticut who settled in Miami in 1925, soon became fascinated with the Everglades' tropical beauty and decided to take action in 1928 by creating the "Everglades Tropical National Park Association." With the support of renowned naturalists, he immediately proposed the creation of the Everglades National Park to the National Park Service. ${ }^{16}$ Together, he and Marjory Stoneman Douglas were convinced that a park could be protected for its biology rather than for its scenery. As historian Jack E. Davis puts it, in the 1930s, at a time when

Congress, the national park service, wilderness advocates, and the public insisted that parks possess something of monumental quality that would distinguish the nation's natural heritage-a towering rock or mountain, a cascading waterfall, or a deep echoing canyon-[...] she and Coe insisted that Americans adjust their panoramic expectations of wilderness. [...] If the Everglades revealed a primitive beauty and realized recreational opportunities, they also bore value in their distinctiveness. With their inclusion, the national park system would more completely represent the grand and diverse canvas of natural America. [...] The arguments hinted at changing standards: biology might supersede scenic monumentalism. The debate over the park also signaled shifting values in the scientific community. The turning point came late on the first day of the December 1930 House committee hearings, when Bumpus, the Park Service's educational director, was testifying. A marine biologist by training, he told the committee that there was 'no single park where you can study the marine life of today.' Representative Phil Swing of California interrupted, 'But Doctor, you are developing a very interesting thought [...] that a piece of ground which has educational value, scientific value, rises to the height of national park value' (Davis, J. E., 368-70).

17 A National Park delegation visited the Everglades in February 1930. Congress passed an historic act to create the park in May 1934 "for the conservation of its notable biological features and of the environment on which they depend" (Davis, J. E., 371). It took another thirteen years to acquire the land, to define the boundaries of the new park and to decide on the fate of the Seminoles. Big Cypress Swamp, originally included in Coe's plan, was excluded from the park project for political and financial reasons, which reduced the park to the southern tip of Florida. During the 1960s, another campaign for a national park began, and led to the creation of Big Cypress National Preserve in 1974. As for the Seminole Indians, after several meetings with the Bureau of Indian Affairs, it was recognized that the tribe had legal ownership of 99,000 acres within the proposed park, a notable fact since before the creation of the Everglades National Park, Indians had never been allowed to stay within park boundaries; they had always been relocated, the National Park Service even prohibiting Indian use of parklands (Davis, J. E., 373-375).

In December 1947, only a few weeks after the publication of her book on the Everglades, Marjory Stoneman Douglass attended the dedication ceremony of the Everglades National Park presided over by President Truman. At the time, she was very confident that the fourth drainage would restore the original Everglades, as demonstrated by the following letter in which she discussed the history of the Everglades and described the U.S. Army Corps of Engineers' plan to restore the water flow:

For over fifty years the agitation to drain the Everglades and use the rich black soil has torn the state and brought, by bungling inadequate methods, all the southern part of Florida very near to ruin. Today, the government of the United States and the State of Florida are working together on a huge project, under a single authority, to carry out the first scientific, well-thought-out plan the Everglades has ever known. 
It is a project of earth moving second, in all our history, only to the majestic scope of the Panama Canal. They are building a system of canals and levees, pumping stations, spillways and water conservation areas which will save and conserve and control all that wonderful sweet water for the crowded cities and farms of the East Coast. It will prevent flooding such as that which, in a single year of excessive rain and hurricane, worked damage to the extent of $\$ 59,000,000$. It will prevent the loss by drowning and starvation of thousands of head of cattle in the growing Everglades cattle industry. ${ }^{17}$ prevent the continuing deterioration of the ecosystem. The effects of The Central and Southern Florida Project for Flood Control and Other Purposes were dramatic: instead of restoring the natural balance of water, the Corps, "unable to grasp the subtle workings of an ecosystem dependent on the divergent meteorological swings of flood and drought, [...] shut down the area's hydrological breathing" (Levin, 9). It was now recognized that the vast flood control system had accelerated the deterioration of the ecosystem to such a level that the Everglades landscape was in great danger. As mentioned in a 1969 Life magazine article entitled "Last Chance To Save the Everglades", the wetlands were now getting instant drought or instant flood, and with the water level fluctuating from one bad extreme to the other, the Corps of engineers had "turned the water supply system in the eastern watershed into a menace instead of a blessing." ${ }^{18}$ By continuing to change the water quality, quantity and seasonal rhythms and by diverting water to crop land, commercial and industrial uses, this last plan had worsened the alteration of the ecological balance of the entire region. Among the identified problems, there was the decline of wading bird populations, the infestation by invasive algae, the deteriorating health of Lake Okeechobee, of the region's estuaries and of Florida Bay, as well as damaging changes related to nutrients in the Water Conservation Areas. In the preface to a 1974 Miami Geological Society report entitled Environments of South Florida: Present and Past, Patrick J. Gleason pointed out the ecological effects of population growth and poorly-planned development in South Florida:

Few people realize the magnitude of man-induced changes in South Florida. Vegetation and wildlife have both been affected. As a result of metropolitan and agricultural development, two large sections of natural vegetation and associated wildlife habitats have been severely altered. The coastal pine forest-tropical hammock flora has almost entirely been removed and about $50 \%$ of the original Everglades marsh has been converted to agricultural land use. ${ }^{19}$

The major consequence of this gigantic drainage in terms of economic development was the purchase of 130,000 acres of land by Florida's biggest producer, United States Sugar Corporation, in the upper Everglades, in the early 1960s, right when the U.S. placed an embargo on Cuban sugar. With this vast acquisition of dry land, sugarcane production rapidly turned into a multi-billion-dollar-a-year industry and, from then onwards, the Everglades Agricultural Area in Central Florida, the world's largest cultivated organic soil bed, became known simply as Big Sugar. ${ }^{20}$ The cultivation of sugarcane, enhanced by the use of chemical fertilizers like phosphorus, continued to expand strongly while polluting the remaining Everglades and disrupting South Florida's natural cycles, as naturalist Ted Levin explains:

Because Big Sugar must remain dry in the wet season, every day more than a billion gallons of water is diverted away from the Everglades [...] for the EAA to grow sugar and vegetables instead of sawgrass (Levin, 209). 


\section{Restoration}

21 Following the new environmental awareness which developed in the 1960s, Florida became a battleground between conservationists and developers, and a testing ground for Florida's environmental policies. In 1972, the Florida legislature established a program called Environmentally Endangered Lands to acquire lands containing relatively unaltered ecosystems or providing habitat for endangered species. This policy of land acquisition has been going on since then and significant purchases have been made. In 1981, a state program called Save Our Rivers allowed the state's management districts to acquire lands deemed necessary to maintain water quality. In 1983, another state program called Save Our Everglades set as its main objective the restoration of the Kissimmee River. In 1994, the State Everglades Forever Act consisted in a massive effort to improve the water quality in the Everglades, with the aim of reducing the level of phosphorus runoff from the sugarcane fields thanks to treatment areas (Levin, 215). During the five years preceding this act, the big sugar companies and vegetable growers of Central Florida fought the cleanup plan at every turn, complaining that they had been turned into scapegoats and that the water-purity standards were unrealistically strict. A series of advertisements sponsored by U.S. Sugar even argued that the restoration plan would spend half a billion dollars making swamp water cleaner than Evian bottled water. ${ }^{21}$

The most ambitious plan to save the ecosystem was the Comprehensive Everglades Restoration Plan (CERP), supported by Vice-President Al Gore and Florida Governor Jeb Bush when submitted to Congress in 1999. Launched by both the federal government and the State of Florida in 2000, at a time when land was being lost to the Everglades at the rate of 2.5 to 5 acres a day, this plan, the largest environmental restoration plan ever undertaken on earth, aims at restoring the hydrological system of the old Everglades and creating a water system that can serve both natural and human needs. ${ }^{22}$ The CERP will cost $\$ 8$ billion to build and $\$ 172$ million a year to operate, a tremendous amount of money considering that, according to estimates by Conservation International, just over half of the project's cost would be enough to buy and protect all the world's rain forests (Levin, 219-220). The project includes sixty-eight engineering projects in sixteen counties and should take at least 35 years to complete. Because drainage canals carry off too much water to the Atlantic, the CERP plans to restore and control flow patterns to both the estuaries and to the fresh water wetlands. ${ }^{23}$ This necessitates capturing and storing as much water as possible. This stored water could then be directed to the south Florida wetlands and also help supply agricultural and urban needs. In addition, the plan will restore some drained lands to natural wetland conditions. In other places, the return to a natural state implies the filling of canals. The rescue plan also includes a project to restore Lake Okeechobee including wetland storage and storm water treatment above and below the lake, and plans to raise roads and eliminate 240 miles of canals and levees. The completion of the Kissimmee River project is also vital to the overall goal of the CERP. Its main aim is to restore the original state of the river with its meanders. Presently, the Comprehensive Everglades Restoration Plan is the only plan which is complete enough to have a chance of saving the Everglades. "It is a test case for the entire country", said Stuart Strahl, the National Audubon Society's Everglades Director. "How well we resolve this will set a precedent for all our remaining environmental crises." ${ }^{24}$ 
However, this restoration enterprise has limits. First, the project itself has suffered almost continuous delays. The main reason for this situation is the rise in costs which may lead to a future lack of state and federal funding. Presently no one knows the final budget amount. As a result of these delays, projects have not been completed and overall progress has been limited. Another important limit is the unknown response of the ecosystem to these restoration measures, given the reduction and deterioration it has suffered. Scientists only have incomplete knowledge of the natural ecosystem. John Ogden, a senior ecologist for the South Florida Water management District, one of the agencies carrying out restoration, explains that

our understanding of the Everglades is based almost entirely on information collected after it became a disturbed ecosystem. We don't know what the natural system really is, so we're basing these projects on a set of predictions on how we think it will respond (Levin, 220).

\section{The current situation}

Today, the wild preserved land called "Everglades", "bridled and balkanized by 1,074 miles of canals, 720 miles of levees, 18 major pumping stations, and 250 control or diversion structures" (Levin, 3), only represents a fraction of the historic ecosystem. ${ }^{25}$

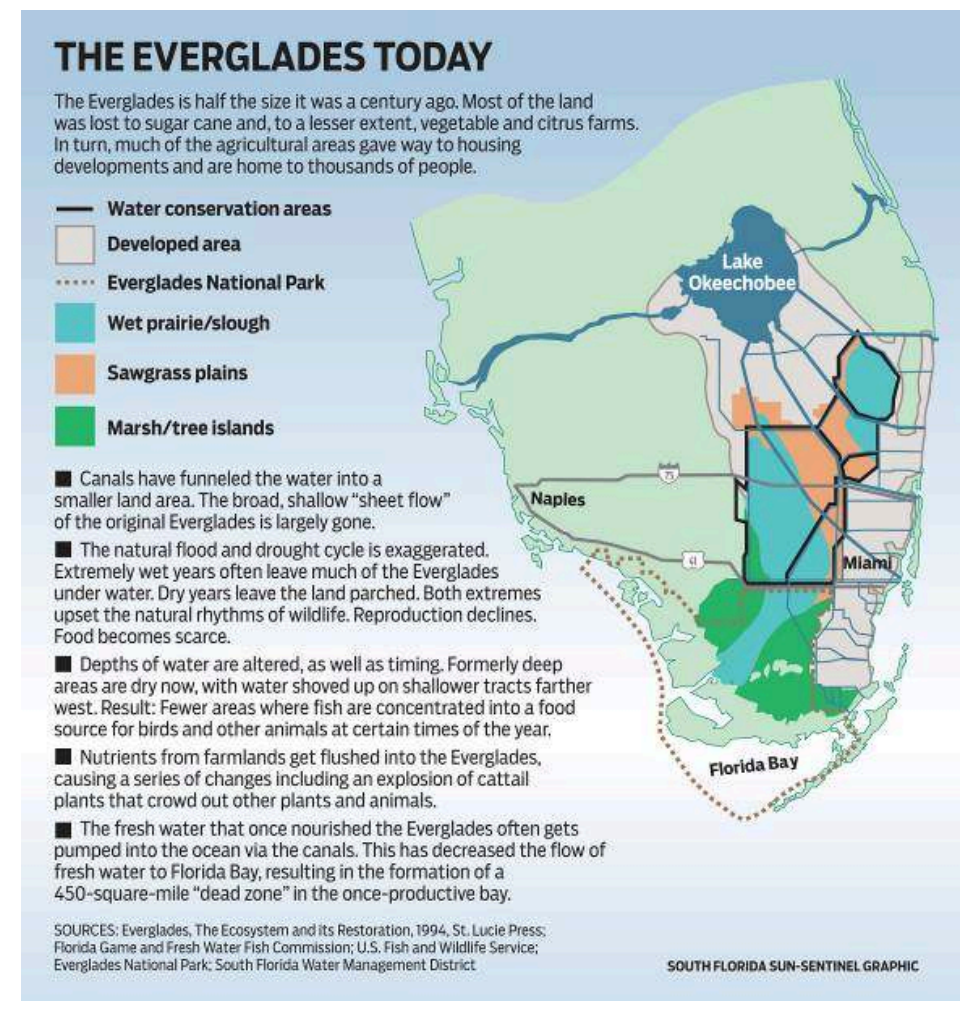

After decades of mismanagement, the damage to wildlife is widespread. The Everglades ecosystem, reduced by half, has suffered huge losses of habitats and species, many of them being either unique to the South Florida ecosystem or playing a key role in the regional environment. The historic pattern which rested on natural factors like hydrology, fire and nutrient supply was altered by human works. In turn, because of the reduction of the habitat, biodiversity has decreased. The number of wading birds has declined by four since the 1930s and some species of birds and mammals are seriously endangered. In the past fifty years, alligators, fish, ibis, wood stork and egrets 
have declined by more than $90 \%$. The Florida panther, the most highly endangered mammal in the U.S., is nearly extinct. Collisions with boats are the leading cause of human-related manatee deaths, while pressure from both leisure fishing and commercial fishing threatens standing stocks of many species. ${ }^{26}$ At the same time, the number of invasive species has increased tremendously. For example, tens of thousands of Burmese pythons, native of Southeast Asia, have been found in the Everglades since the 1990s, often making the headlines because they represent a threat for both the vegetation and the fauna of the Everglades; they have been responsible for the disappearance of nearly all middle-sized mammals from the ecosystem in the last twelve years; other animals like bobcats, foxes, deer and rabbits are decreasing because of their competition with pythons for food. ${ }^{27}$ In addition, many exotic plants are also a threat to the Everglades' original environment, the most resistant one probably being melaleuca, a tree native to Australia which, in densely affected areas, crowds out native plants and sucks up water at such a rate that it interferes with the natural flow of the water. Michael Grunwald, the author of The Swamp, The Everglades, Florida, and the Politics of Paradise, explains how Florida's leading conservationist, John Gifford, first imported melaleuca from Australia to help drain the Everglades, proudly asserting that with its voracious appetite for water, it was a "natural swamp tree"(Grunwald, p. 129). Today, trying to eradicate this devastating, water-hungry plant is one of the many challenges that defenders of the ecosystem face. As a result, the impact of the restoration plan is truly difficult to predict; moreover, the effects of the continuing rise in the sea level will greatly affect an ecosystem situated just above it. Indeed, sea levels are expected to rise three to four feet by the end of the twenty-first century, enough to put much of Florida-including the Everglades and the Keys-under water. ${ }^{28}$

Harmed by more than a century of dredging and development, the remaining parts, whose fate is absolutely dependent on water, have been vastly altered by hydrological changes and water pollution, and reduced by suburban sprawl which, west of Fort Lauderdale, Palm Beach and Miami, for example, numbers millions of people pressed against the eastern ribs of the Everglades, all dependent upon a finite supply of freshwater. In April 2011, Kirk Fordham, CEO of the Everglades Foundation, recalled in the Miami Herald that

one in three Floridians depend directly on the Everglades for their daily supply of fresh water. Whether it is their drinking water or water to fill their swimming pools, irrigate their lawns or wash their cars, more than six million residents could not survive without this source of water. ${ }^{29}$

And yet, many Floridians remain reluctant to comply with water restrictions, despite the freshwater crisis. Many landowners, for example, refuse to restrict watering their gardens to twice a week, even during the rainy season, and remain convinced that watering seven days a week is appropriate, fearing that they may have to pay a fine to their Homeowners Associations if their grass turns brown. Among other water uses showing the abuse of Everglades beyond human need, are the impressive numbers of hotels with indoor pools or ocean side pools, and of residents with privately owned outdoor pools in backyards or gardens (more than one million pools in 2006) ${ }^{30}$, the dozens of water parks, the multitude of artificial ponds built over the past two decades in gated communities, and the record number of golf courses in the United States-a record Florida has held since the 1950s. With the rising water needs of Florida's farms and cities and the flood of new residents expected in the decades to come-the Florida population is set to double to 33 million by $2050^{31}$-it seems very unlikely that the CERP 
will be able to undo the extensive damage and also prevent the state's booming economy from drying up. And yet, Florida's commercial pillars such as tourism are inextricably linked to their environment and clearly depend on Everglades restoration to supply freshwater to cities, farms and factories. Paradoxically, the powerful sugar industry that created much of the problem is playing a very minor role the in the restoration of the Everglades. In June 2008, Florida Governor Crist announced a \$1.75 billion deal to buy U.S. Sugar Corporation, the nation's largest sugar producer, including 87,000 acres of farmland that lie in the middle of the proposed conservation area in the northern Everglades. The idea was to use the sugar land to construct a network of reservoirs to clean and store water before sending it south into the Everglades National Park. ${ }^{32}$ But in August 2010, because of political opposition and fiscal deterioration since the 2008 economic crisis, it was announced that Governor Crist could only secure 27,000 acres, a fraction of the original size, for $\$ 197$ million. ${ }^{33}$ Clearly, the result is that sugar barons have had to pay only for a fraction of the cost to correct the situation while the government-that is, taxpayers-will certainly have to pay for the rest. ${ }^{34}$

In July 2010, the United Nations' World Heritage Committee inscribed the Everglades National Park on the "List of World Heritage Sites in Danger", declaring that the Everglades was still being jeopardized by serious and continuing degradation of its aquatic system:

Water inflows have been reduced by up to 60 per cent and nutrient pollution increased to the point where the site is showing significant signs of eutrophication, loss of marine habitat and a subsequent decline in marine species. ${ }^{35}$

In its original decision document, the World Heritage Committee recalls that it is the second time the Everglades have been included on the List of World Heritage in Danger. They were first inscribed in 1993, following damage caused by Hurricane Andrew, and a marked deterioration in water flows and quality resulting from agricultural and urban development. It was removed from the Danger List in 2007, in recognition of efforts to restore the Park and its wider ecosystem, a decision that infuriated Florida Democrats and environmentalists who claimed that progress was not sufficient: the restoration project was less than half-finished, was years behind schedule due to bureaucratic delays, and was also billions of dollars over budget because of a lack of financing from Congress. ${ }^{36}$

In 2010, the World Heritage Committee acknowledged the fact that the degradation of the site had continued and that the Everglades were

endangered by neighboring urban growth, pollution by fertilizers and poisoning of fish and wildlife by mercury, falling water levels due to flood protection measures and by hurricane damage to Florida Bay. ${ }^{37}$

To conclude, the importance of the Everglades has been recognized both nationally and worldwide, and an unprecedented, pharaonic project to protect and restore its waters, lakes and streams has been implemented to return the natural flow of water from Lake Okeechobee into the Everglades. But progress has been slow and the results remain to be seen. As Park Superintendent Jack Raftery explained already in 1969, the Everglades' interconnected watershed is "a demonstration that no natural region can be divorced from its surroundings." ${ }^{38}$ Complex ecosystems being easier to destroy than to rebuild, the ambitious CERP project, although it may slow down the rate of decline, is a test of whether or not it is possible to return the ecosystem to its previous stable state, and of how much human interference the Everglades can still tolerate. But with such an 
unhealthy environment due to continuing urban sprawl and pollution from agricultural activity, and despite years of conservation efforts to "permanently safeguard an irreplaceable primitive area" 39 going far beyond the borders of the national park, the Everglades undeniably remain under great threat in spite of the protection they benefit from which is, by definition, incomplete.

\section{BIBLIOGRAPHY}

Ake, Anne. Everglades: An Ecosystem Facing Choices and Challenges. Sarasota: Pineapple Press, 2008.

Davis, Jack E. An Everglades Providence: Marjory Stoneman Douglas and the American Environmental Century. Athens: University of Georgia Press, 2009.

Davis, Steven M., and Ogden, John C; (editors). Everglades, The Ecosystem and Its Restoration. Delray Beach: St. Lucie Press, 1994.

Douglas, Marjory Stoneman. The Everglades: River of Grass. Georgia: Mockingbird, 1947 (2 ${ }^{\text {nde }}$ éd. 1974).

Grunwald, Michael. The Swamp, The Everglades, Florida, and the Politics of Paradise. New York: Simon \& Schuster, 2006.

Levin, Ted. Liquid Land, A Journey through the Florida Everglades. Athens: The University of Georgia Press, 2003.

Lodge, Thomas E. The Everglades Handbook: Understanding the Ecosystem. Boca Raton: CRC Press, 2004.

McCally, David. The Everglades, an Environmental History. Gainesville: University Press of Florida, 1999.

Myers, Ronald L, and Ewel, John J. Ecosystems of Florida. Orlando: University of Central Florida Press, 1990.

Stronge, William B. The Sunshine Economy, An Economic History of Florida since the Civil War. Gainesville: University Press of Florida, 2008.

\section{NOTES}

1. United States Bureau of Census, “2010 Census Demographic Profiles”, Web. 7 August 2011 http://2010.census.gov/2010census/data/index.php

2. The difference between "protection" and "preservation" is that the latter implies to impose durable protection against damage, which involves the management of natural resources. The concept of "conservation", which also includes a wise use of natural resources, involves social and economic considerations as well. "Restoration" is placed under the heading of conservation as "restoration of sufficient diversity and area of habitats" which are essential to "conservation" and refers to re-establishment and creation of biotopes (Heijnsbergen, P. Van, International Legal Protection of Wild Fauna and Flora, Amsterdam: IOS Press 1997: 44-48). 
3. A map of Florida lakes and rivers is available at:

http://geology.com/lakes-rivers-water/florida.shtml

("Florida Lakes, Rivers and Water Resources", 14 August 2011).

4. As Marjory Stoneman Douglass observed, "The truth of the river is the grass. The saw grass and the water made the Everglades both simple and unique. [...] The saw grass in its essential harshness supports little else. It repelled man" (Douglas, 1947, 5, 28).

5. Graighead, F. C., Land, Mangroves and Hurricanes, Fairchild Tropical Garden Bulletin, 1964, pp. $1-5$.

6. For a description of the Everglades ecosystem, see Ake, Anne, Everglades: An Ecosystem Facing Choices and Challenges, Sarasota: Pineapple Press, 2008.

7. Davis, T. Frederick. “The Disston Land Purchase.” The Florida Historical Quarterly, Vol. 7, issue 3 (January 1939): 204.

8. Light, Stephen S. and Dineen, J. "Walter, Water Control in the Everglades: A Historical Perspective", in Davis, Steven M., and Ogden, John C; (editors), Everglades, The Ecosystem and Its Restoration, Delray Beach: St. Lucie Press 1994: 53.

9. Iatarola, Louis M. "The Life and Influence of Hamilton Disston", The Historical Society of Tacony (June 2009): 6; by 1900, cane sugar had been produced in Florida for almost a century, but the center of the industry was in the northeast of the state, where farmers also grew cotton and tobacco (Stronge, 4-5).

10. Before then, there had been a few sugar plantations in Florida, but they were small farms, and many growers did not live there year-round but only during the dry season, from fall to spring (Light, Stephen S. and Dineen, J. Walter: 58).

11. The reference to "Other Purposes" implied that besides saving lives and farms in case of floods, the project also aimed at allowing urban development and promoting economic growth.

12. To see the expansion of the canal and levee system in Florida from 1911 to 1970, click here:

http://sofia.usgs.gov/sfrsf/rooms/historical/soils/past.html

(29 February 2012).

13. Based on an extensive survey of the Everglades, it was decided that the designated EAA area was the upper Everglades "where the organic soils were sufficiently deep and of the proper physical composition to warrant development for farming" (Snyder, G.H., and Davidson, J.M., Everglades Agriculture: Past, Present and Future, p. 99, in Davis, Steven M., and Ogden, John C; (editors), Everglades, The Ecosystem and Its Restoration, Delray Beach: St. Lucie Press, 1994.)

14. A map of the various land-use areas is available on the National Park Service website at http://science.nature.nps.gov/im/units/sfcn/waterrs1.3.cfm

("Kissimmee River Restoration and Upper Basin Initiatives", 20 August 2011).

15. Douglas, Marjory Stoneman. "Letter to Mrs. Frank Jennings, Jacksonville, Fla" Kissimmee: 6 December 1928. The Seminoles are a Florida Native American tribe. The majority of its members were forced to settle in the present state of Oklahoma during the nineteenth century Indian Removal. A few hundreds of them resisted deportation and found refuge in the Everglades to escape the U.S. army during the Third Seminole War of 1855-1858. There are now about 3,000 Seminoles living on several reservations in Florida (90,000 acres altogether). The tribe's thriving economy is based on agriculture (citrus), crafts, tourism, tobacco and gaming enterprises.

16. Coe, Ernest. "Correspondance, Everglades National Park" Presidential Papers, Everglades National Park, 1926-1934.

17. Douglas, Marjory Stoneman. "What Are They Doing To The Everglades?" Unpublished manuscript, 1947.

18. MacDonald, John. "Last Chance to Save the Everglades" Life, 5 September 1969: 59-64. 
19. Gleason, Patrick J, "Environments of South Florida: Past and Present”, Miami Geological Society, Miami, November 1974: 5.

20. "Environment: Lady of the Everglades" Time, 31 January 1983.

21. Elmer-DeWitt, Philip, and Booth, Cathy. "Facing a Deadline to Save the Everglades" Time, 21 June 1993.

22. Sanders, Alain L. "Political Foes Join to Save Florida Everglades" Time, 1 July 1999.

23. To view and compare the historic, current, and planned CERP flow of water through the greater Everglades ecosystem, interactive flow maps are available on the CERP website: Water Flow Maps of the Everglades: Past, Present and Future, Web. 16 August 2011

http://www.evergladesplan.org/education/flowmaps.html

24. Padgett, Tim. "Last Stand" Time, 5 July 1999.

25. In a 2008 Fort Pierce article, journalist Ed Killer was also wondering how long the Hoover Dike would continue to protect surrounding cities from floods: "Quite regularly, the lake rises 40 inches in only two weeks, often reaching a level only a few feet below what the Corps considers an unacceptable risk to the Hoover dike. For example, in 2005, the Corps was forced to perform heavy releases to prevent the dike from failing, having to take massive discharges that dumped 10 years of water supply out of the lake" (Killer, Ed, "Environmental Damage Expected from Lake O Releases" Fort Pierce Tribune, 5 September 2008).

26. These recreational and commercial boats traversing shallow flats and running aground also erode banks of waterways, releasing solids into the waterway and damaging shoreline habitat (Ogden, John C, "The Use of Conceptual Ecological Models to Guide Ecosystem Restoration in South Florida" in Wetlands, Vol. 25, No. 4 (December 2005): 804).

27. McGrath, Susan. "Attack of the Alien Invaders" National Geographic, March 2005; Padgett, Tim. "Florida Wrestles with Its Python Problem" Time, 10 July 2009.

28. Walsh, Bryan. "Climate-Change Report: From Bad to Worse" Time, 17 June 2009.

29. Fordham, Kirk. "Why We Need Everglades Restoration” Miami Herald, 7 April 2011.

30. Florida Department of Health, "Survey of Residential Swimming Pools Assessed by Florida County Property Appraisers" Summer 2006, Web. 7 August 2011

http://www.doh.state.fl.us/injury/PDF/ResidentialSwimmingPoolSurvey.pdf

31. Population projections are anticipating that the state population will reach nearly 33 million by 2050, ranking Florida the third state in the nation after California and Texas. Florida Department of Transportation, 2010-2050 Projections by District, Web. 9 August 2011

http://www.dot.state.fl.us/planning/policy/demographic/2000-2050.pdf

32. Cave, Damien. "Florida to Buy Sugar Maker in Bid to Restore Everglades" The New York Times, 25 June 2008; "Sugar and Grass" The Economist, 11 December 2008.

33. Grunwald, Michael. "Florida Everglades Cleanup: A River of Morass" Time, 11 December 2010.

34. Barlett, Donald L., and Steele, James B. "Corporate Welfare: Sweet Deal" Time, 23 November 1998.

35. World Heritage Committee, Unesco Decision, Everglades National Park, Web. 9 August 2011

http://whc.unesco.org/en/decisions/4137/

36. Padgett, Tim. "Has Bush Abandoned the Everglades? "Time, 10 August 2007; Cave, Damien. "Harsh Review of Restoration in Everglades "The New York Times, September 30, 2008.

37. United Nations Environmental Program, World Conservation Monitoring Centre, Everglades National Park, Web. 7 August 2011 www.unep-wcmc-apps.org/sites/wh/pdf/Everglades.pdf

p. 1.

38. "Conservation: Jets v. Everglades" Time, 22 August 1969. 
39. Quote from President Truman's Address on Conservation at the Dedication of Everglades National Park on December 6, 1947.

\section{ABSTRACTS}

The Everglades constitute a unique ecosystem situated in Southern Florida. This marshy region was considered as inhospitable in the nineteenth century. The transformation of Florida into a vacation and retirement paradise during the twentieth century was made possible by draining and developing vast portions of the wetlands for agricultural and urban purposes, which dramatically altered the Everglades by taking its freshwater supply necessary for a tremendous population growth. The purpose of our paper is to explore the environmental disaster left by human beings over this unique ecosystem and to focus on the recent attempts at restoring the remaining Everglades. Can this threatened ecosystem be saved?

Les Everglades constituent un écosystème unique situé au sud de la Floride. Cette région de marécages était considérée comme inhospitalière au dix-neuvième siècle. La transformation de la Floride en paradis de vacanciers et de retraités au cours du vingtième siècle a été rendue possible grâce à des drainages successifs qui ont mis à jour des terres nouvelles sur lesquelles agriculteurs et résidents se sont rapidement installés, mais qui ont également considérablement altéré le fonctionnement d'un écosystème extrêmement complexe, tout en réduisant la quantité d'eau douce censée répondre aux besoins croissants d'une population en perpétuelle augmentation. Notre article traite des dommages causés par l'homme sur les Everglades puis des diverses tentatives de restauration d'un patrimoine naturel unique. Cet écosystème menacé peut-il réellement être sauvé ?

\section{INDEX}

Mots-clés: Floride, Everglades, Parc National des Everglades, Lac Okeechobee, Indiens Séminoles, Indiens Miccosukee, marécages, drainage, canaux, inondations, écosystème, espèces invasives, eau, restauration, canne à sucre, Bureau des affaires indiennes

Keywords: Florida, Everglades, Everglades National Park, Lake Okeechobee, Sunbelt, Seminole Indians, Miccosukee Indians, swamp, drainage, canals, floods, ecosystem, invasive species, water, restoration, Army Corps of Engineers, U.S. Sugar Corporation, Comprehensive Everglades Restoration Plan (CERP)

\section{AUTHORS}

\section{JANINE LEMAIRE}

Associate Professor

Aix-Marseille University

janine-lemaire@wanadoo.fr 
BÉNÉDICTE SISTO

Associate Professor

Blaise Pascal University, Clermont-Ferrand

benedicte.sisto@wanadoo.fr 